\title{
Soybean in No-Till Cover-Crop Systems
}

\author{
Mosab Halwani ${ }^{1, *}$, Moritz Reckling ${ }^{1,2} \mathbb{D}^{\text {, Johannes Schuler }}{ }^{1}{ }^{\circledR}$, Ralf Bloch ${ }^{1,3}$ \\ and Johann Bachinger ${ }^{1}$ \\ 1 Leibniz Centre for Agricultural Landscape Research, 15374 Müncheberg, Germany; \\ moritz.reckling@zalf.de (M.R.); schuler@zalf.de (J.S.); bloch@zalf.de (R.B.); Jbachinger@zalf.de (J.B.) \\ 2 Department of Crop Production Ecology, Swedish University of Agricultural Sciences, \\ 75007 Uppsala, Sweden \\ 3 Faculty of Landscape Management and Nature Conservation, \\ Eberswalde University for Sustainable Development, 16225 Eberswalde, Germany \\ * Correspondence: Mosab.Halwani@zalf.de
}

Received: 31 October 2019; Accepted: 10 December 2019; Published: 13 December 2019

\begin{abstract}
Introducing agro-ecological techniques such as no-tillage systems with cover crops in rotations with soybean (Glycine max (L.) Merr.) could provide more resilience to changing climatic conditions and, at the same time, reduce soil erosion, nitrate leaching, and weed density in the main crop. However, there are challenges in introducing no-tillage techniques in crop systems in Europe as there is little quantitative knowledge about the agro-economic impact. The objectives of this study were to evaluate the agronomic and economic impacts of three soybean cropping systems involving a rye (Secale cereal L.) cover crop prior to soybean, i.e., two no-tillage systems; either herbicide-free with crimping the rye or herbicide-based without rye crimping and one plough-based in which rye was cut as green silage. The impacts of these cropping strategies were compared in a three-year cropping system experiment at a research station in north-eastern Germany with and without irrigation. The following parameters were measured: (1) cover crop biomass; (2) weed biomass; (3) soybean plant density; (4) soybean grain yield; and (5) gross margin of the cropping system. The results showed that all three soybean cropping systems can effectively suppress weeds. System (C), the no-tillage herbicide-based system, produced the lowest rye biomass and highest soybean yield; system (B), the no-tillage herbicide-free/crimped rye system, produced the highest rye biomass and lowest soybean yield compared to system (A), the standard cutting/plough-based system. The differences in rye biomass and soybean yield observed between the three systems could be mainly attributed to the timing of the cover crop termination and the soybean sowing date. The gross margin was highest in system (C), due to the high soybean grain yield. The low soybean grain yield in system (B) resulted in lower revenues and gross margins compared to systems (A) and (C), although system (B) could be economically attractive in organic farming with higher prices for organic soybean. In the particularly dry year 2016, gross margins were higher when soybean was irrigated compared to the rainfed cultivation, due to significantly higher grain yields. Before recommending the application of the no-tillage with cover crop technique for the conditions tested in north-eastern Germany, more investigations on the benefits and risks of this technique are needed. Further research needs to focus on maintaining a high rye biomass as well as on ensuring an early soybean planting date. Optimizing the crimping and drilling equipment is still required in order to develop good management practices for no-tillage herbicide-free systems in European conditions.
\end{abstract}

Keywords: no-tillage; cover crop; irrigation; weed suppression; gross margin 


\section{Introduction}

Climate change has adverse effects on crop production in Europe [1]. Adaption to climate change is crucial especially for grain legumes [2] and other spring crops that tend to have low yield stability [3]. Adaptation options include adjusting the crop management, choice of cultivars and design of the cropping system $[4,5]$. Northern Germany is expected to be affected by climate change including an increase in average annual temperature, shifts in seasonality of precipitation (decreased in summer, increased in winter), shifts in potential evaporation, increasing incidence of milder winters, an increased frequency of periods of drought and heavy precipitation, and an extended vegetation period [6].

As a consequence, the cool-season grain legumes such as lupins, field peas and faba beans are likely to respond with a reduced yield stability that has been observed in long-term field experiments over the last 60 years [7] and will not be able to take advantage of the higher temperatures and increase in vegetation period. Consequently, soybean (Glycine max (L.) Merr.) as a warm-season grain legume could benefit from these higher temperatures and longer vegetation periods in central Europe and provide an alternative to the cool-season grain legumes [8,9]. The cultivation of soybean in Europe is done as a summer annual grain crop using short-day adapted varieties. Late sowing dates of soybean in May means that a cover crop could be included prior to soybean planting to cover the soil during winter. However, little is known on cover crops used before grain legume sowing.

The main driver for growing cover crops prior to grain legumes, besides reducing wind and water erosion and increasing soil organic matter, is weed suppression before and during the growing season [10]. This is important since soybean is very sensitive to weed infestation especially in low-input and organic farming [11]. The mechanisms of weed suppression by cover crops are diverse and depend, besides other factors, on the termination method. A common approach uses broad spectrum herbicides based on glyphosate and atrazine to terminate the cover crops. Mechanical cutting and grazing can also be used to kill cover crops. A novel approach for cover crop termination is crimping, using a roller-crimper [12]. With all these approaches, the cover crop mulch layer inhibits the weed physically (due to shading), chemically (allelopathy) or by direct competition for resources [13].

Prevailing production systems couple cover crops with conservation tillage (CT) to enhance the ecological benefits e.g., no-tillage cover-crop systems after legume crops is the most common conservation agriculture (CA) application known to optimize utilization of nitrogen, thereby reducing nitrate leaching [14]. The use of cover crops in CA adds also further environmental benefits such as soil erosion control, increases soil organic carbon and thus enhancing soil fertility [15] as well as improvement of soil properties, microflora and fauna [16].

While such no-tillage cover-crop systems are more common for growing soybean in the US [17,18], their agronomic and economic potentials and limitations have not been investigated under Central European conditions except for the study by Weber et al. [12] in organic farming. To investigate the agro-economic potential of the novel no-tillage cover-crop systems in soybean, a three year field experiment was established on sandy soils in north-eastern Germany. The objectives were to assess the agronomic effects of the different cover crop systems on (i) soybean plant density, (ii) cover crop biomass, (iii) weed suppression and (iv) soybean grain yield as well as (v) the related economic opportunities and limitations of growing soybean in no-tillage cover-crop systems.

\section{Materials and Methods}

\subsection{Study Site}

The study was implemented in north-eastern Germany in the federal state of Brandenburg. A field experiment was conducted at the research station of the Leibniz Centre for Agricultural Landscape Research (ZALF) in Müncheberg (52 $31^{\prime}$ N, 14 ${ }^{\circ} 7^{\prime}$ E, 60 m.; NE Germany). Soils in the research station are from glacial deposits and are predominantly sandy loams and loamy sands with a high spatial heterogeneity containing on average $61 \%$ sand, $27 \%$ silt and $12 \%$ clay. The soil $\mathrm{pH}(\mathrm{KCl})$ ranges between 6.1 and 6.9 , the total soil carbon between $4 \mathrm{~g} \mathrm{~kg}^{-1}$ and $7 \mathrm{~g} \mathrm{~kg}^{-1}$ and the plant available water holding 
capacity is estimated at $150 \mathrm{~mm}$ in the rooting zone of $1 \mathrm{~m}$. During the last 40 years the climate measured in the experimental field in Müncheberg showed that the mean annual temperature increased from $8.5^{\circ} \mathrm{C}$ in the period $1970-2000$ to $9.0^{\circ} \mathrm{C}$ in the period of $1980-2010$. There was also an increase in the annual precipitation rate in the same period from $521 \mathrm{~mm}$ p.a. to $565 \mathrm{~mm}$ p.a. However, this increase was combined with a shift in the precipitation distribution with more precipitation in the winter months (Jan., Feb.) and less in April and more heavy precipitation events in the summer months [19]. During the study period from 2015-2017, the annual precipitation varied from $451 \mathrm{~mm}$ in the dry year in 2016 to $635 \mathrm{~mm}$ in 2017. Monthly rainfall totals and average temperatures for each year are presented in the results section.

The study took place on three different fields over three successive growing seasons, starting in fall 2014 with the establishment of winter rye (Secale cereal L.) as a cover crop. The experiments were designed by scientists, influenced by farmers' interests and constraints in managing weeds effectively without additional weeding or herbicide applications, following Reckling et al. [5].

\subsection{Design of the Field Experiments}

All treatments were arranged in a split-plot design with four replications. Whole plots consisted of cropping systems while subplots were irrigation (with/without) that was omitted in 2015 and 2017, when precipitation was sufficient and irrigation was unnecessary. Individual plots were $8.5 \mathrm{~m} \times 12 \mathrm{~m}$ in size.

Three cropping systems were compared:

- System (A) — a standard "cutting/plough-based system", in which the previous rye cover crop was cut and removed, and plots were tilled immediately to $23 \mathrm{~cm}$ deep by reversible plow combined with packer to level the seedbed in spring (9-17 May). Then soybean was sown with a standard drill at the optimal time (11-19 May).

- System (B)—a "no-tillage herbicide-free system", where the previous rye cover crop was crimped at rye flowering (18-27 May), left on the field and soybean sown with a direct seeding drill immediately, without any later chemical regulation of weeds.

- System (C) - a "no-tillage herbicide-based system", in which the previous rye cover crop was killed with a broad-spectrum systemic herbicide (glyphosate) at the end of stem extension period (11-29 April) when the most mature rye was at booting stage (BBCH: 31); with no further soil tillage, soybean sown with a direct seeding drill at the optimal sowing time (11-17 May, similar to system (A)) and with subsequent application of pre-emergent and post-emergent herbicides.

All soybean crops followed a winter rye cover crop that was established in autumn (27 Sept-10 Oct) using a standard drill in $10 \mathrm{~cm}$ rows at 250 seeds $\mathrm{m}^{-2}$. In 2017, the seeding rate was increased to 350 seeds $\mathrm{m}^{-2}$. For weed management a single broadcast application for pre-emergence herbicides was applied (Table 1).

The soybean cultivar Merlin (maturity group 000) was planted at a rate of 65 seeds $\mathrm{m}^{-2}$ in 2015 and 80 seeds $\mathrm{m}^{-2}$ in 2016 and 2017. Adjustments were needed to increase the rate of emergence, especially in the system where the cover crop was crimped. All three systems were tested with and without irrigation. Irrigation was applied as needed, depending on rainfall events. Irrigation amounts and timing were modelled with the Web-BEREST irrigation software. Web-BEREST calculates the irrigation water based on the crop demand using the coefficient of actual to potential evapotranspiration. Detailed information on the model assumptions and equations are provided by Mirschel et al. [20]. 
Table 1. Schedule of field operations, in Müncheberg, from 2015 to 2017.

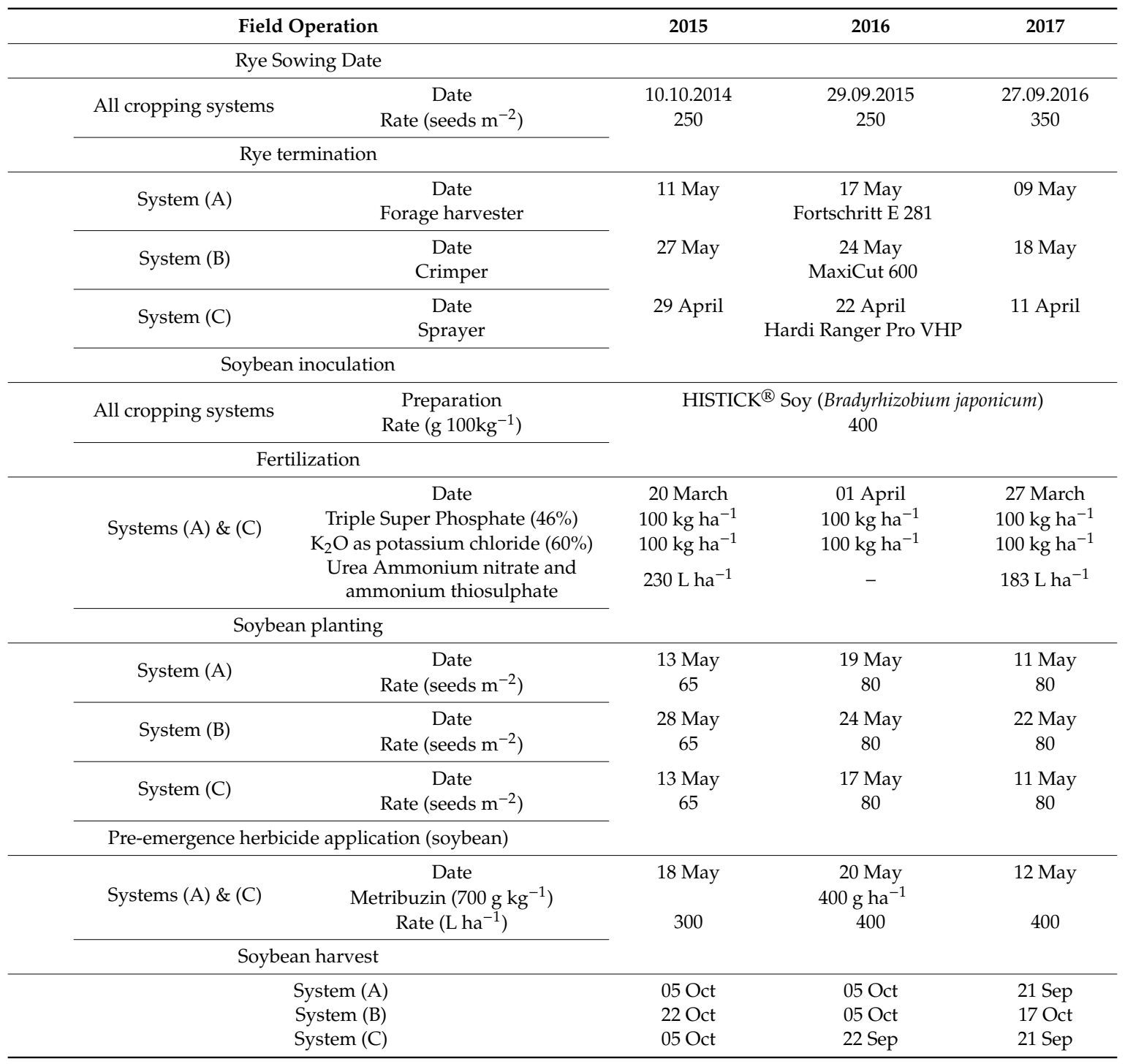

\subsection{Data Collection}

Biomass of cover crop was measured in April for system (C) and May for systems (A) and (B), prior to termination, by clipping plants at the soil level from a single $0.5 \mathrm{~m}^{2}$ quadrat per replication.

Plants were dried at $65^{\circ} \mathrm{C}$ for $48 \mathrm{~h}$ and weighed to determine dry weight per plot. Soybean density was measured 12 days after planting, and soybean/weed stand was measured in late July, by clipping all plants within a single $0.5 \mathrm{~m}^{2}$ quadrat for each replication. Soybean and weeds plants were separated to determine the fresh and dry weight. Soybean yield was determined between 5-22 October through the machine-harvesting operation of mature plants within 15-17 $\mathrm{m}^{2}$. System (B) was omitted in 2015 when soybean density data were analyzed, due to difficulty in seeding through thick rye residue and poor plant stand.

A simple economic calculation was performed. Revenues were calculated for each cropping system i.e., the rye biomass and soybean grain yield and producer prices for both rye biomass and soybean grain in Germany from 2018. The variable costs included all inputs i.e., seeds, inoculum, fertilizers, herbicides and operations for soil tillage, sowing, fertilizer application, rye termination, harvesting, irrigation and/or harvesting of rye green biomass. The price for conventional soybean grain was $350 € \mathrm{t}^{-1}$ and the price of organic soybean grain was $800 € \mathrm{t}^{-1}$ in 2018 , with $71 \%$ higher seed costs for organic than for conventional seeds. The price for rye biomass was valued at $78.6 € \mathrm{t}^{-1}$. 
The rye residues that were crimped or killed by herbicide and which remained on the field after the termination were not assigned any economic value.

\subsection{Statistical Analysis}

Data were subject to two-way ANOVA, using the SAS ${ }^{\circledR}$ 9.2 PROC MIXED procedure (SAS Institute Inc., Cary, NC, USA), after satisfying the assumptions for normality and homogeneity of variance. When an interaction was not significant, it was removed from the model, and the data were reanalyzed without the interaction.

Two-way-ANOVA, followed by Tukey's post hoc test, was performed to compare the main effects of cropping system and year for the plots without irrigation and the interaction effect between cropping system and year on soybean yield, rye and weed biomass.

Additionally in 2016, Two-way-ANOVA, followed by classical t-tests between different treatments within irrigation and followed by Tukey's post hoc test between different treatments within cropping system, was performed to compare the main effects of cropping system and irrigation and the interaction effect between cropping system and irrigation on soybean yield and weed biomass. The cropping systems included three types (systems (A), (B), and (C)), data were collected for three years $(2015,2016$, and 2017), and two irrigation conditions were considered (with and without irrigation).

Linear regression was performed to identify potential relationships between soybean grain yields and weed biomass under all three cropping systems. Additionally, regressions were used to identify potential effects of rye biomass in system (B) on soybean yield and weed biomass. The Pearson's correlation coefficients were calculated using the software SAS ${ }^{\circledR} 9.2$ PROC REG procedures for multivariate data analysis (SAS Institute Inc., Cary, NC, USA).

\section{Results}

\subsection{Climate}

Cumulative precipitation during the 5-month growing season (May-September) was at least $12 \%$ higher than the 25-year average of $308 \mathrm{~mm}$ in 2017, but only 70\% of the 25-year average in 2016, and only $64 \%$ of the 25 -year average in 2015 . Moreover, distribution of precipitation did not favor soybean germination in 2016, since less than $5 \mathrm{~mm}$ was received during May, this lower amount was only $9 \%$ of precipitation received in 25-year average of $55 \mathrm{~mm}$.

Distribution of precipitation during the growing season also favored soybean seed production in 2017, with greater-than-average amounts of precipitation occurring during June and July when the majority of soybean vegetative and reproductive growth typically occurs in northeastern Germany.

Monthly growing-season temperatures were near the 25 -year average of $16.3^{\circ} \mathrm{C}$ in 2015 and 2017, $1.3{ }^{\circ} \mathrm{C}$ warmer than the 25-year average in 2016. Temperatures in June and July were comparable to the 25-year average in three experimental years (Table 2).

\subsection{Soybean Plant Density}

There was a significant interactions for soybean plant density between cropping system and year $(p=0.0003$ ) (Figure 1). In 2017, soybean densities differed with the cropping system, with significantly higher soybean densities at system (A) compared to system (B) and system (C). In 2016 and 2015, higher soybean densities were found in system (C) compared to system (A) and system (B), however, these differences were not significant. In all systems, soybean densities in 2016 were reduced on average by 50\% from the target plant density and ranged from 30 to 40 plants $\mathrm{m}^{-2}$. Soybean density in 2017 achieved consistent soybean densities between 60 and 75 plants $\mathrm{m}^{-2}$ (Figure 1). 
Table 2. Mean temperature, precipitation and irrigation amounts (in parentheses) from 2015-2017.

\begin{tabular}{ccccccccc}
\hline & \multicolumn{3}{c}{ Mean Temperature $\left({ }^{\circ} \mathbf{C}\right)$} & \multicolumn{5}{c}{ Precipitation $(\mathbf{m m})$} \\
\cline { 2 - 9 } & $\mathbf{2 0 1 5}$ & $\mathbf{2 0 1 6}$ & $\mathbf{2 0 1 7}$ & $\mathbf{2 5 - Y e a r ~ M e a n}$ & $\mathbf{2 0 1 5}$ & $\mathbf{2 0 1 6}$ & $\mathbf{2 0 1 7}$ & 25-Year Mean \\
\hline January & 1.3 & -0.8 & -1.6 & -0.1 & 67.0 & 32.0 & 25.7 & 40.3 \\
\hline February & 5.4 & 3.5 & 1.5 & 1.1 & 4.7 & 39.4 & 26.8 & 29.4 \\
\hline March & 8.6 & 4.2 & 6.8 & 4.0 & 39.3 & 22.7 & 41.5 & 36.4 \\
\hline April & 12.7 & 8.4 & 7.8 & 9.1 & 17.4 & 18.8 & 21.7 & 29.7 \\
\hline May & 16.1 & 15.5 & 14.3 & 13.8 & 21.9 & $4.9(15)$ & 41.8 & 55.4 \\
\hline June & 19.3 & 18.4 & 17.6 & 16.6 & 42.1 & 91.2 & 110.1 & 56.3 \\
\hline July & 21.5 & 19.3 & 18.4 & 18.9 & 47.7 & $52.3(75)$ & 114.6 & 81.4 \\
\hline August & 13.9 & 17.7 & 18.6 & 18.2 & 18.0 & $45.1(10)$ & 55.6 & 64.9 \\
\hline September & 7.9 & 16.9 & 13.3 & 14.0 & 66.7 & 20.4 & 24.0 & 49.8 \\
\hline October & 6.9 & 8.4 & 11.2 & 9.2 & 55.1 & 48.7 & 72.7 & 40.1 \\
\hline November & 6.5 & 3.4 & 5.44 & 4.3 & 66 & 32.5 & 67.5 & 39.0 \\
\hline December & 1.3 & 2.4 & 3.2 & 1.2 & 27.0 & 42.9 & 32.9 & 36.7 \\
\hline Annual & 10.2 & 9.8 & 9.7 & 9.2 & 472.9 & 450.9 & 634.9 & 559.6 \\
\hline
\end{tabular}

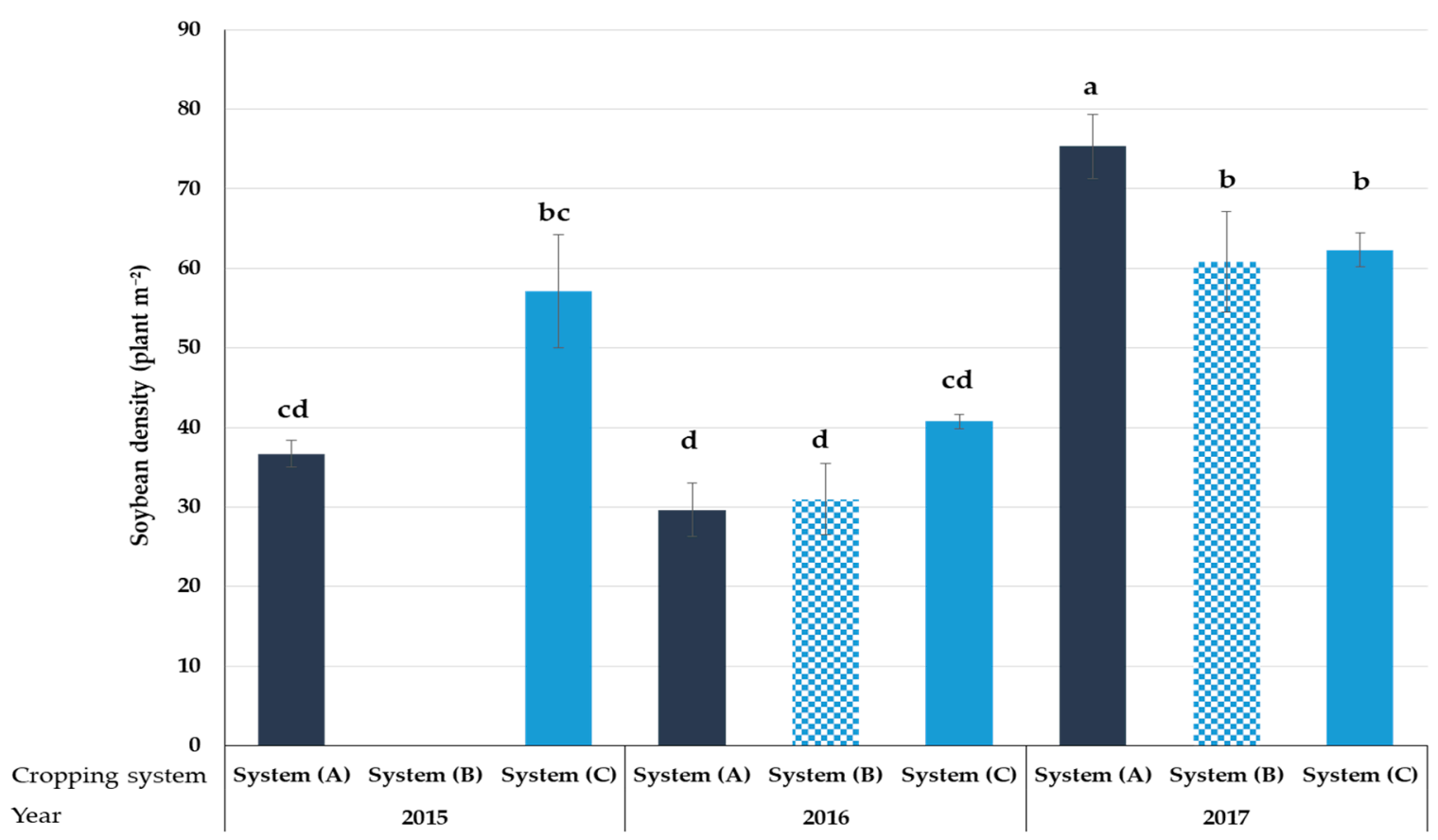

Figure 1. Interaction effect of cropping system on soybean density at Müncheberg, Germany, in 2015 to 2017. ( $p=0.0003$ ). Abbreviations: System (A), Cutting/plough-based system; System (B), No-tillage herbicide-free system; System (C), No-tillage herbicide-based system. Standard error bars are presented $(n=8)$. Means in the same year followed by the same letter are not significantly different at $p \leq 0.05$. The soybean density from system (B) in 2015 was excluded in data analysis because there were no plants to sample (see Section 2.3. Data collection).

\subsection{Cover Crop Biomass}

A two-way analysis of variance was conducted on the influence of cropping system and year on rye biomass. Significant interactions were detected between year and cropping systems $(p<0.001)$ (Figure 2). 


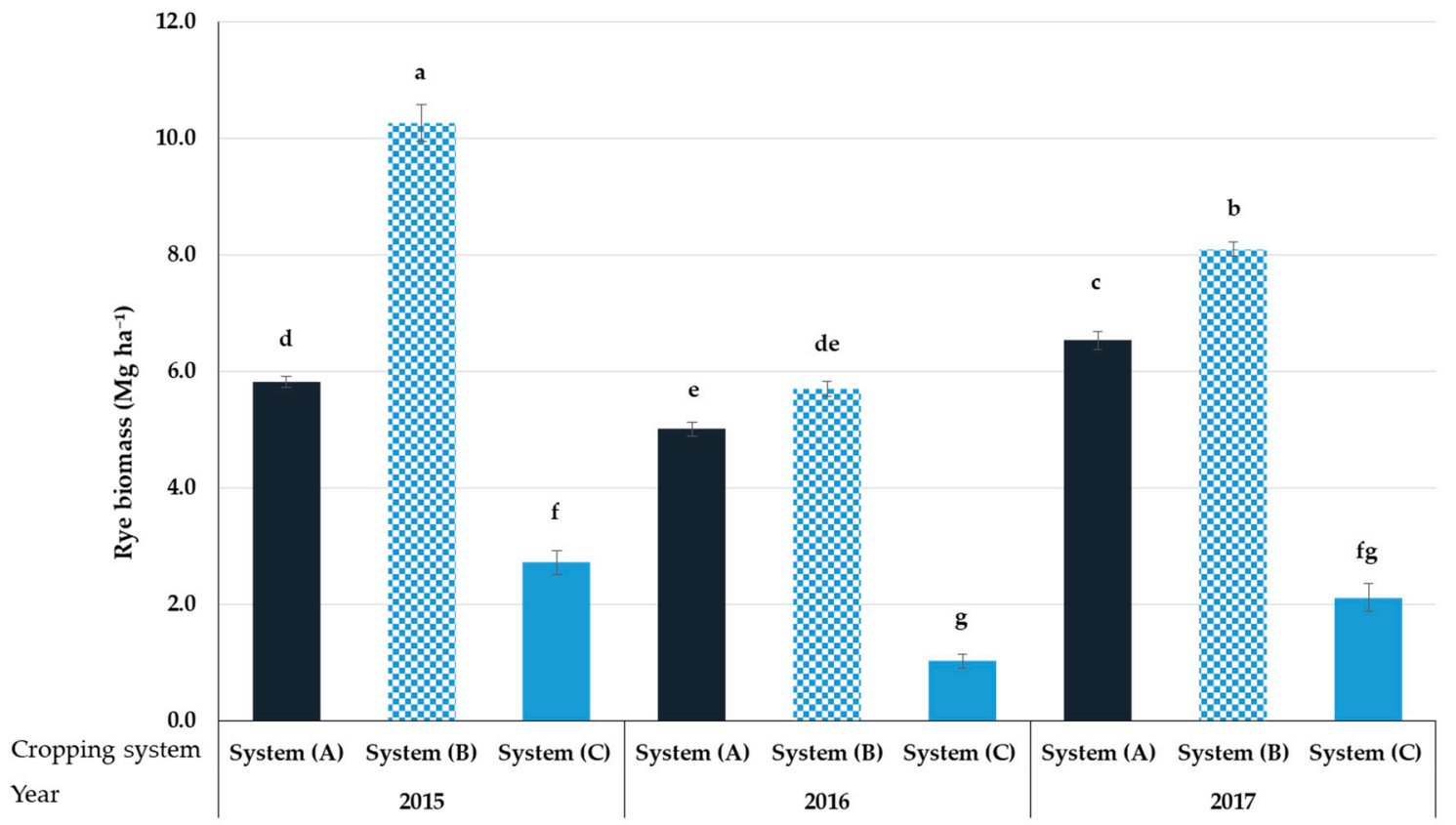

Figure 2. Interaction effect of cropping system on rye biomass at Müncheberg, Germany, in 2015 to 2017 ( $p<0.001$ ). Abbreviations: System (A), Cutting/plough-based system; System (B), No-tillage herbicide-free system; System (C), No-tillage herbicide-based system. Standard error bars are presented $(n=8)$. Means in the same year followed by the same letter are not significantly different at $p \leq 0.05$.

The dry weight of rye shoot biomass at the time of treatment with glyphosate at system (C) was significantly lowest in all years, whereas the dry weight of the mowed rye at the system (A) was intermediate. Biomass was the highest in no-tillage herbicide-free system in system (B) (Figure 2), with no significant difference between system (A) and system (B) in 2016.

\subsection{Weed Suppression}

There was a significant interaction between cropping system and year for weed biomass without irrigation $(p<0.001)$. Weed biomass at soybean flowering was not affected by the cropping system in 2017. In 2016, weed biomass in system (C) was significantly less than in systems (A) and (B). Thus, both conservation tillage systems (B) and (C) can effectively suppress weeds similarly to standard ploughed system (A) (Figure 3).

There was no significant interaction effects for weed biomass in 2016 between cropping system and irrigation $(p=0.23)$, while the main effects of cropping system and irrigation were significant. Irrigation in 2016 increased significantly weed biomass $(p=0.006)$ in all three cropping systems. There was a significant difference between systems $(p=0.0003)$, with system $(C)$ having significant lower weed biomass than system (A) and system (B) (Figure 4).

Soybean grain yield was only weakly correlated with weed biomass in all cropping systems (Intercept $=30.25 \pm 3.06$ and slope $=-0.74 \pm 0.34$ adjusted $R^{2}=0.248, p=0.049$ ). There was a strong negative correlation between rye cover crop biomass at the time of termination and weed biomass in the following soybean crop (Intercept $=58.17 \pm 3.93$ and slope $=-0.69 \pm 0.05$ adjusted $R^{2}=0.937$, $p<0.001$. 


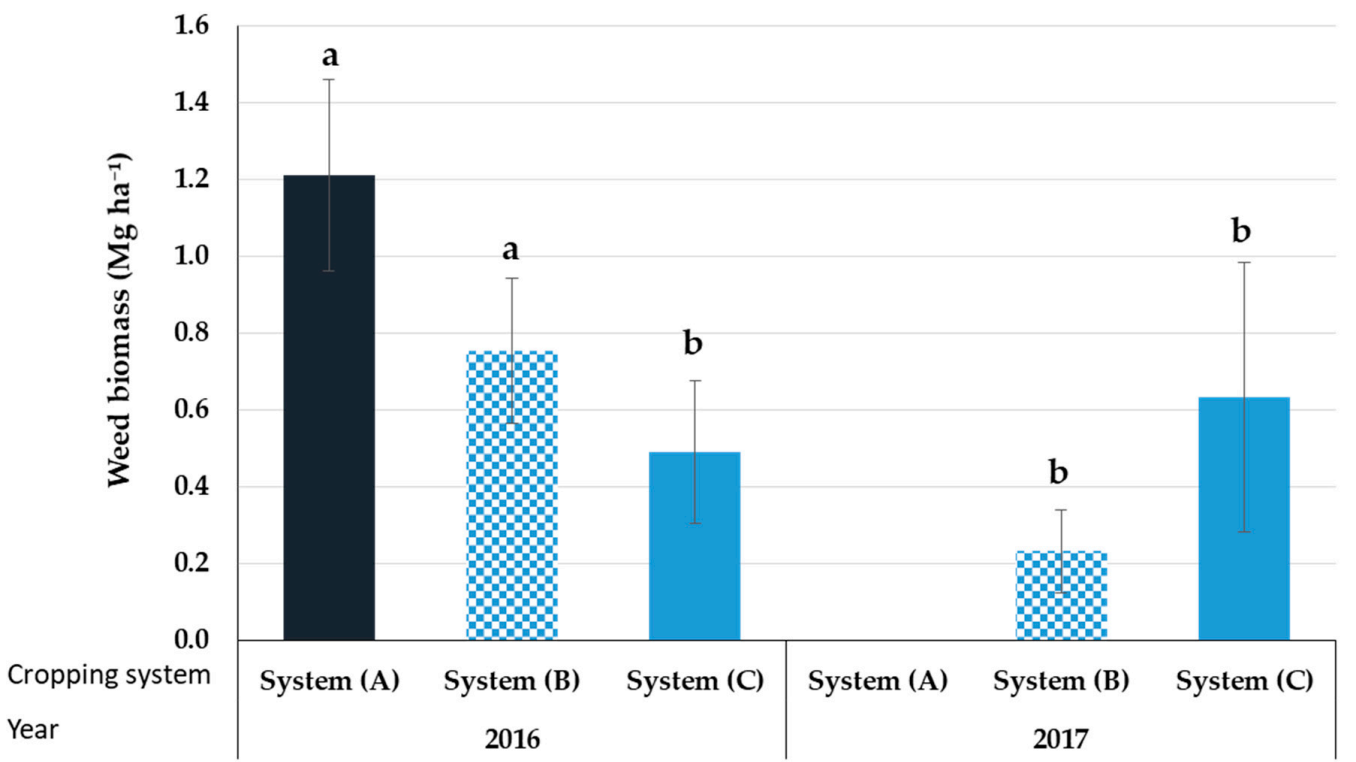

Figure 3. Interaction effect of cropping system on weed biomass without irrigation at Müncheberg, Germany, in 2016 and 2017. Abbreviations: System (A), Cutting/plough-based system; System (B), No-tillage herbicide-free system; System (C), No-tillage herbicide-based system. Standard error bars are presented ( $n=4$ in 2016 and $n=8$ in 2017). Means in the same year followed by the same letter are not significantly different at $p \leq 0.05$. The weed biomass from system (A) in 2017 was excluded in data analysis because there were no weeds found.

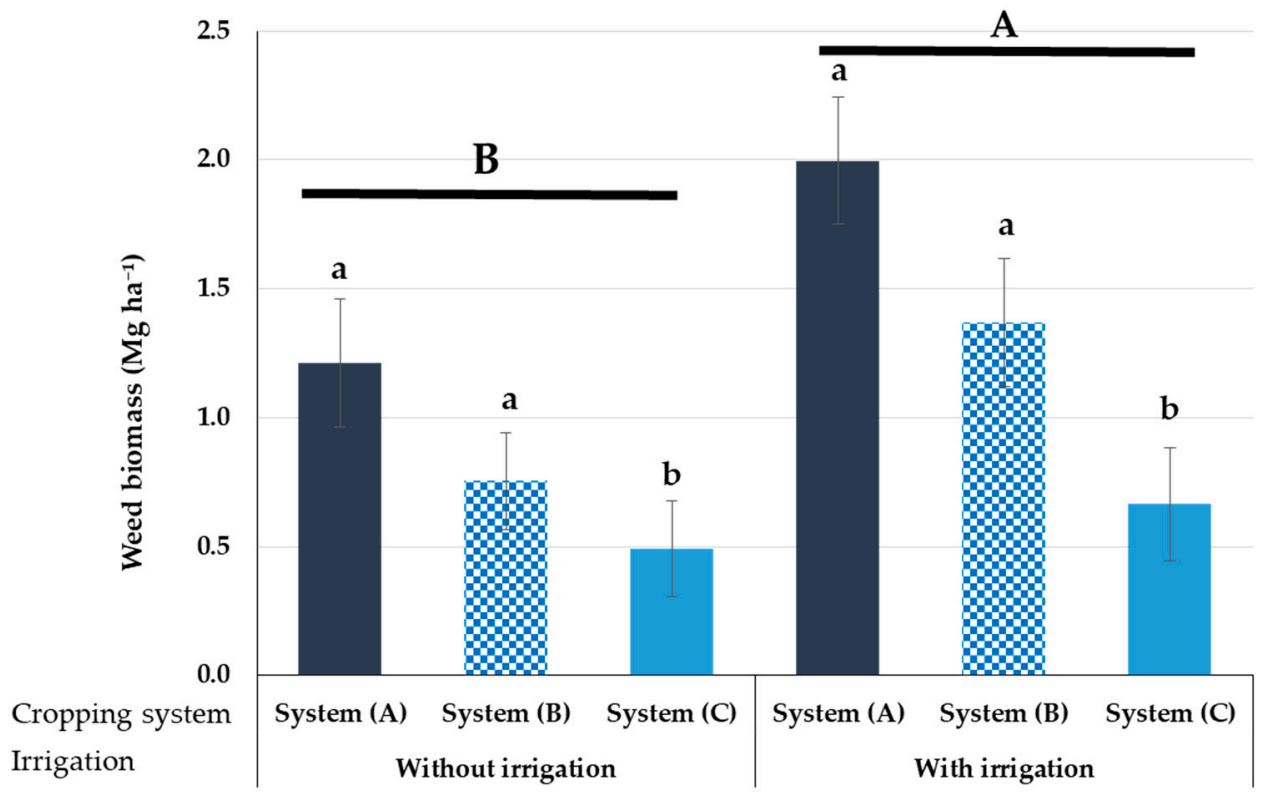

Figure 4. Effect of irrigation on weed biomass under three cropping systems at Müncheberg, Germany, in the dry year 2016. Abbreviations: System (A), Cutting/plough-based system; System (B), No-tillage herbicide-free system; System (C), No-tillage herbicide-based system. No interaction effect $(p=0.23)$. Standard error bars are presented $(n=4)$. Means followed by the same letter are not significantly different at $\mathrm{P} \leq 0.05$. Lowercase letters allow for comparison among cropping system $(\mathrm{P}=0.0003)$. Uppercase letters allow for comparison between with and without irrigation $(p=0.006)$.

\subsection{Soybean Yield}

There was a significant interaction for soybean yield between cropping system and year under rainfall conditions $(p<0.001)$ (Figure 5). In 2015 no differences could be detected between cropping 
systems. While system (C) outperformed system (A) and (B) in 2016, system (C) was not statistically different from system (A) and system (B). Otherwise, a significant difference was observed between system (A) and system (B) in 2017 (Figure 5).

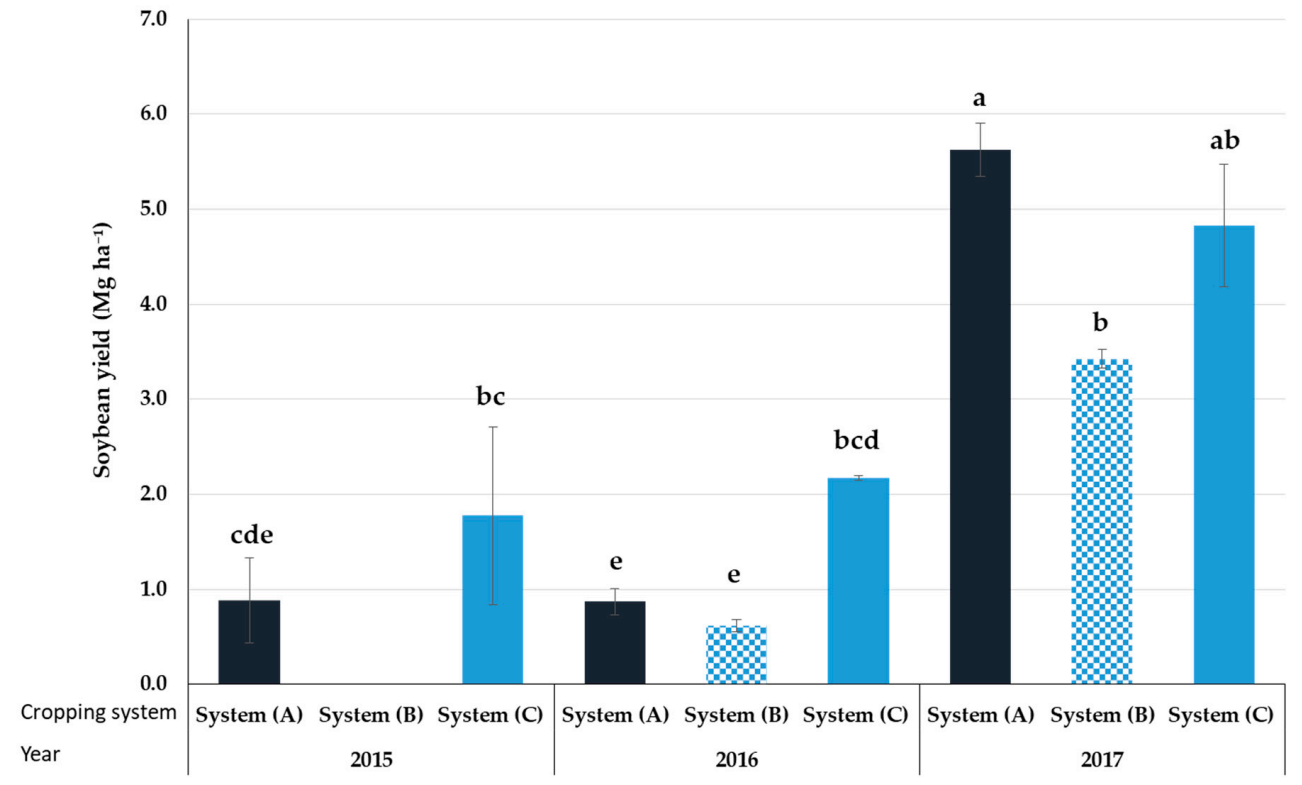

Figure 5. Interaction effect of cropping system on soybean yield without irrigation at Müncheberg, Germany, in 2015 to 2017. Abbreviations: System (A), Cutting/plough-based system; System (B), No-tillage herbicide-free system; System (C), No-tillage herbicide-based system. Soybean yield were analyzed separately each year, due to a significant interaction between years and cropping systems $(p<0.001)$. Standard error bars are presented $(2015$ and $2017 n=8,2016 n=4)$. Means in the same year followed by the same letter are not significantly different at $p \leq 0.05$. The soybean yield from system (B) in 2015 was excluded in data analysis because there were no plants to sample (see Section 2.3. Data collection).

In 2016, there were significant two-way interactions for soybean yield between cropping system and irrigation $(p=0.02)$. With and without irrigation, system (C) outperformed system (A) and (B) and there was no significant difference between system (A) and system (B) (Figure 6). Grain yield responded to irrigation in all systems. These responses to irrigation were highest in system (B) (264\% higher yield with irrigation), compared to system (A) (105\% higher yield with irrigation) and the lowest effect, but highest absolute yields were found in system (C) (61\% higher yield with irrigation).

\subsection{Economic Results}

Economic results were affected by the cropping system, the presence of irrigation and differences in prices. System (A) achieved a gross margin of $380 € \mathrm{ha}^{-1}$ in the rainfed system, which was lower than system (C) with $463 € \mathrm{ha}^{-1}$. The gross margin for system (B) was negative with a conventional price $\left(-172 € \mathrm{ha}^{-1}\right)$ and positive with an organic price $\left(447 € \mathrm{ha}^{-1}\right)$. The main differences between the cropping systems resulted from the differences in soybean revenues, which were $975 € \mathrm{ha}^{-1}$ in the standard system (A), $1254 € \mathrm{ha}^{-1}$ in system (C), and $557 € \mathrm{ha}^{-1}$ in system (B) if the price of conventional soybean was used, $1176 € \mathrm{ha}^{-1}$ when the organic price was assumed. The second difference in the cropping system came from the variable costs, which were $1052 € \mathrm{ha}^{-1}$ when the rye biomass was harvested, and the field was ploughed (system (A)), $696 € \mathrm{ha}^{-1}$ when the rye was crimped (system (B)), and $792 € \mathrm{ha}^{-1}$ when rye was killed with the contact herbicide (system (C)). This amount was broken down into the cost for rye cultivation, which was equal for all systems, as well as the costs for soybean cultivation and rye termination, which were varied between the cropping systems (Figure 7). 
In all three systems, the use of irrigation increased the variable costs by $270 € /$ ha on average in 2016 compared to rainfed cultivation. The largest effects on the additional revenues from irrigation in 2016 were achieved in system (B) which responded best to the addition water supply (Figure 8).

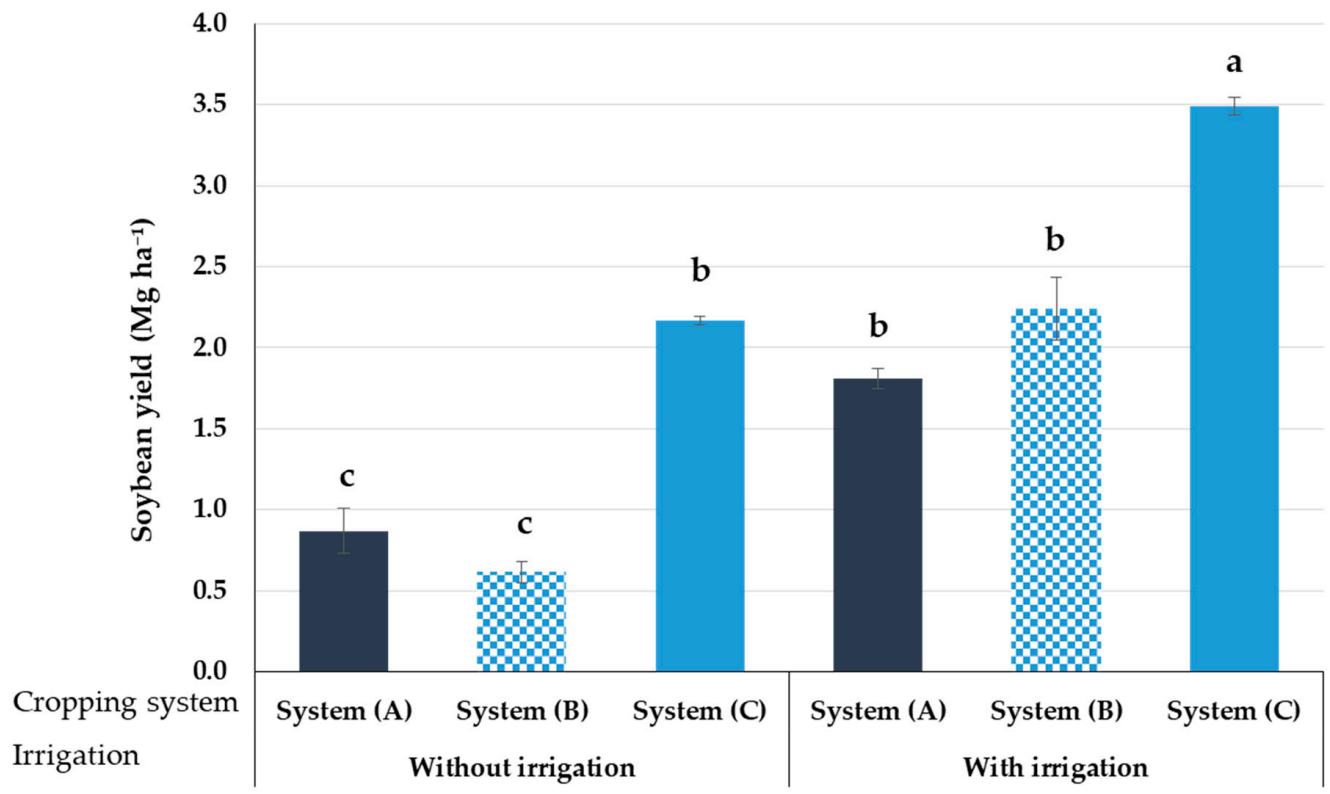

Figure 6. Interaction effect of irrigation on soybean yield under three cropping systems at Müncheberg, Germany, in dry year 2016. Abbreviations: System (A), Cutting/plough-based system; System (B), No-tillage herbicide-free system; System (C), No-tillage herbicide-based system. Interaction effect $(p=0.02)$. Standard error bars are presented $(n=4)$. Means followed by the same letter are not significantly different at $p \leq 0.05$.
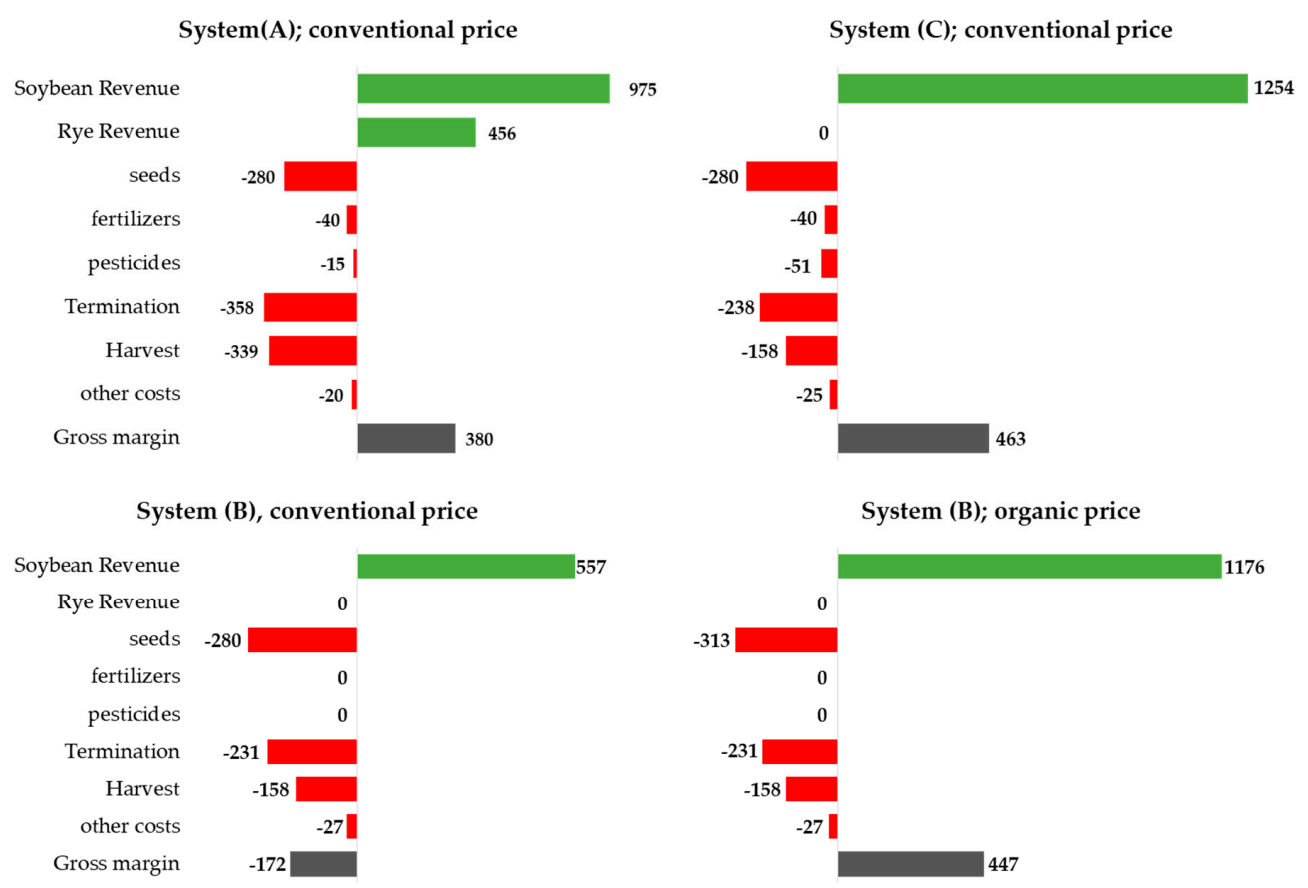

Figure 7. Comparison of average revenue, variable cost and gross margin for two no-tillage systems and tillage system from 2015 to 2017, all without irrigation. Abbreviations: System (A), Cutting/plough-based system; System (B), No-tillage herbicide-free system; System (C), No-tillage herbicide-based system. 

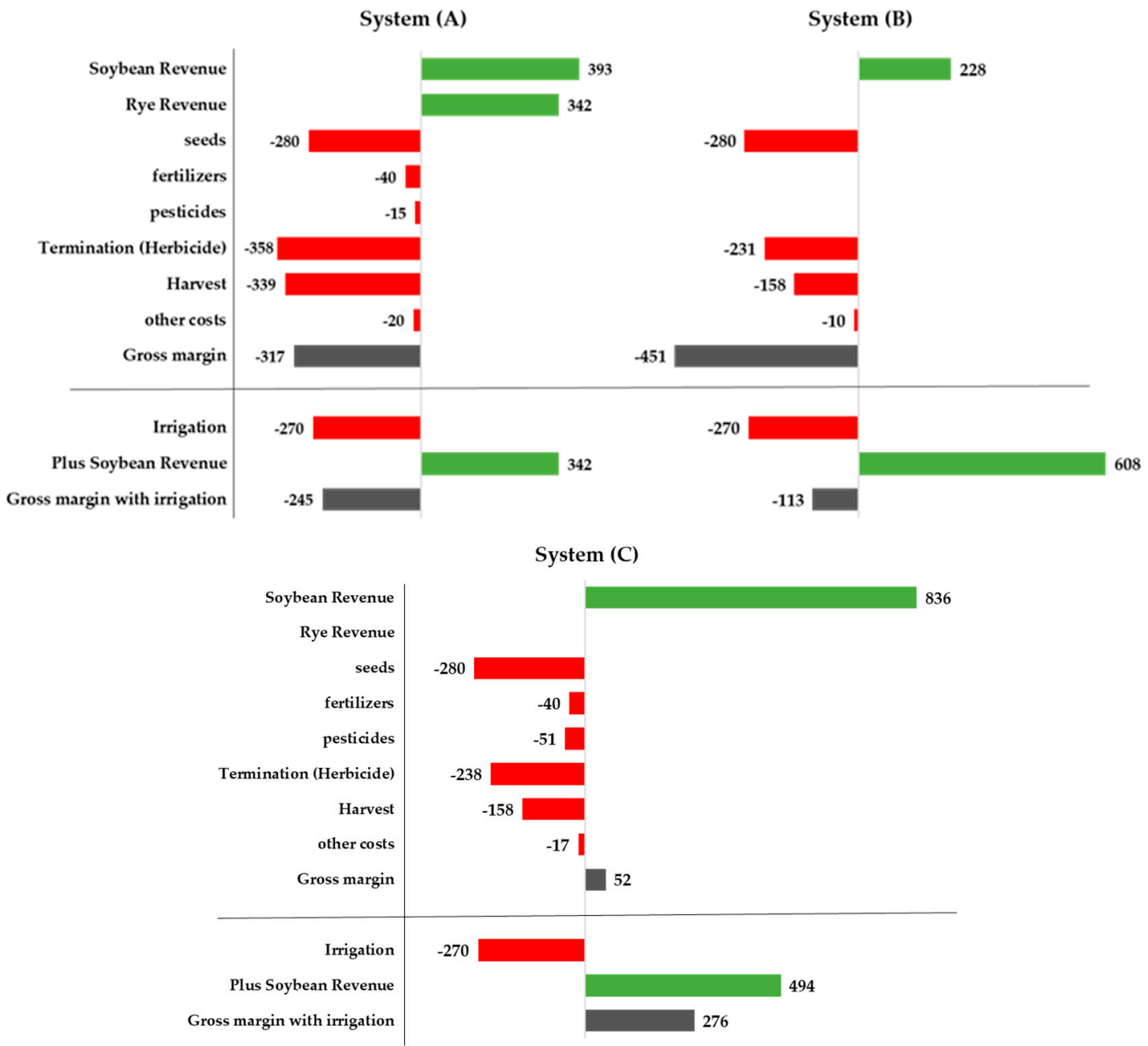

Figure 8. Comparison of gross margin for two no-tillage systems and tillage system under irrigated and without irrigation in the 2016 drought year. Abbreviations: System (A), Cutting/plough-based system; System (B), No-tillage herbicide-free system; System (C), No-tillage herbicide-based system.

\section{Discussion}

In central Europe, soybean production is only possible annually during summer, when the danger of frost ends. This poses a major challenge to sustainable agriculture, requiring to maintain ground cover over the winter months. For this reason, the interest in cover crops prior to soybean planting in central Europe is increasing [21]. Cover crops are preferred not just because they reduce wind and water erosion and increase soil organic matter but also because they have weed-suppressing effects before and during the growing season [22]. Terminating cover crops by plough is not suitable for sustainable agriculture, since soil disturbance should be minimized within this system.

In this trial, using two no-tillage cover-crop systems, weeds were managed during the soybean growing season equally or better than by using the cutting/plough-based system (system (A)). However, a higher soybean yield was obtained with the no-tillage herbicide-based system (System (C) than with the cutting/plough-based system, which outperformed the no-tillage herbicide-free system (System (B)).

The date of termination differed among the cropping systems in this trial, and that could have a major effect on the sowing dates and finally, the yields. Rye in system (C) was terminated at the booting stage to maximize the effectiveness of glyphosate, which decreases when plants reach reproductive stages $[23,24]$. The cutting date of rye in system (A) was at the head emergence stage to maximize yield and feed quality traits $[25,26]$. In system (B), rye could only be terminated at anthesis 
(flowering) stage, following the recommendations of Keene et al. [18] in Canada, and Ashford and Reeves [27] in the northern USA, and thereby increasing the effectiveness of the roller-crimper for killing rye. The late cover crop termination in system (B) prevented an early soybean sowing date, which is needed for achieving high yields in no-tillage herbicide-free systems. Previous research suggested strategies to allow an earlier planting date, i.e., using earlier-flowering rye cultivars $[17,28]$, planting rye earlier $[10,26,29-31]$, planting soybean at the boot stage of rye cultivars with low regrowth potential [32,33], and planting soybean into standing rye prior to termination.

\subsection{Soybean Productivity}

The variation in soybean yield among cropping systems was largely influenced by the differences in soybean establishment. This makes it difficult to attribute this effect to the different features of the soil tillage systems. In our trial, the use of glyphosate to terminate the cover crop in the no-tillage system had the potential to achieve higher or similar soybean yields compared to those obtained using a standard cutting/plough-based system, whereas using a crimper to terminate the cover crop in the no-tillage system appeared to be less successful in this regard.

The typical soybean planting date in eastern Germany is from late April to mid-May [8]. However, soybean following crimped rye (system (B)) was planted during late May in this study to allow the cover crops to reach anthesis, thus facilitating better roller-crimper efficacy $[17,27,34-39]$. This delayed the planting date of soybean and subsequently limited the yield potential $[40,41]$. Soybean in the systems (A) and (C) was sown earlier than in system (B), providing the plants more time to establish and fill the pods, which is important considering that soybean is a short-day plant, sensitive to the photoperiod when grown in summer in Europe [42,43]. Conversely, a late planting date of soybean in system (B) resulted in a less vigorous vegetative growth, a lower number of branches able to produce pods, and a lower soybean yield potential per plant [41,43]. Additionally, the longer growing time of the cover crop often results in increased water use in the growing season. This, in turn, reduces the soil moisture available to soybean, which potentially increases the risk of a dry soil profile [28,35]. Moreover, Flower et al. [10] indicated that late killing of the cover crop reduces soil water storage. While cover crops are known to improve water retention (especially during winter), they are not able to offset crop yield declines that may occur because of temperature and water stress [19,30].

Soybean densities were lower for all systems in 2016 compared to 2017. Low soybean densities could be partially responsible for the relatively low soybean grain yields in 2016 for all systems compared to 2017. Higher plant densities result in canopy closure earlier in the season, which can be conducive to increased light interception, reduced soil moisture loss, prevention of the establishment of early-emerging weed, and increased crop yield [36,37]. Cumulative precipitation from May to September in the warmer year of 2016 was lower than in 2017, which could partly explain the yield differences between the two years. In dry years, the plants were often extremely short, and the lowest pods were very close to the ground, which increased losses during harvesting [37,38,40,42]. Mandić et al. [39] pointed out the importance of rainfall for soybean grain yield in north Serbia. Their study concluded that soybean grain yield had a strong positive relationship with the amount of rainfall during the growing season, especially in May, July, and August.

In 2016, in system (C), soybean produced higher yields than in systems (A) and (B), possibly because soil moisture was reduced after tillage during the harsh drought spring or was reduced by transpiration during cover crop growth until its flowering $[24,33,34,36]$. This theory is supported by the results of Bernstein et al. [33], who showed that after late rye termination in a dry year, soil moisture at depths below $20 \mathrm{~cm}$ was more reduced in a no-tillage system than in ploughed systems.

\subsection{Cover Crop Biomass}

Rye cover crop biomass was the lowest in system (C) compared to systems (A) and (B) in all years. Rye in the system (A) built intermediate rye biomass until the cutting date. The earlier termination dates of rye cover crops contributed to an apparent reduction in biomass of sprayed and mowed rye 
compared to the biomass of rolled-crimped rye. Rapid accumulation of rye biomass occurred in system (B) (roller-crimped) over the 28-37 days after the application of glyphosate in system (C) or 9-16 days after cutting in system (A). Previous research from Pennsylvania (USA) showed a37\% increase in biomass with each 10-day delay in cover crop termination in spring [44].

In addition to the rye termination date, rainfall strongly influenced rye biomass accumulation. Rye biomass was lower in all systems in 2016 compared to 2015 and 2017. Differences in monthly precipitation from March to May during the study period explain why biomass results varied among these years. The rye cover crop was exposed to drought stress during the vegetative rye growth in 2016, which reduced the rye biomass production. This finding is in agreement with Alonso-Ayuso et al. [45], who showed that the above-ground biomass was double in a typical or humid year than in a dry year. Also, Idowu and Grover [46] found that a major challenge of cover crop adaptation in dry areas is the availability of water to grow cover crops.

\subsection{Weed Suppression}

Termination methods of rye suppressed weeds prior to soybean growing season, in system (A) during mechanical cutting and by ploughing the top soil layer, in system (B) during mechanical crimping and in system (C) by application of glyphosate that killed not only rye but also the weeds. Pre-emergence herbicide was applied in systems (A) and (C) to regulate weeds during the soybean growing season. Rye as a cover-crop in the crimped system (B) regulated weeds through mechanical (crimping) and biological suppression by inhibiting the germination of weed seeds (due to shadow and allelopathy) or by direct competition for resources [13]. In our trial, the use of both no-tillage cover-crop systems suppressed the weed and formed less or similar weed biomass compared to the standard cutting/plough-based system. Our results indicate efficiency of weed suppression in no-tillage systems with additional practices such as mechanical in system (B) or chemical system (C) including cover crops [10,47].

The weed biomass in 2017 was significantly lower than in 2016. This observation might be attributed to low precipitation in 2016, which had a greater effect on rye biomass at the termination date and the loss of rye residues than in the humid year 2017. Smith, et al. [48] found an increased weed competition within the row in conditions with low rye biomass. Furthermore, cover crop biomass was negatively correlated with weed density. This is in agreement with Witter, et al., [49] who showed that the higher the cover crop biomass, the lower the weed density. Insufficient soil moisture [28], inadequate seed placement [40], and poor seed-to-soil contact [31] can explain the influence of cover crop biomass on weed emergence in soybean.

\subsection{Irrigation}

Plots were only irrigated in 2016 because of insufficient rainfall from May to September. The use of irrigation increased soybean yields in our study (in 2016) and other investigations [50,51]. Drought stress at the critical phases, i.e., from flowering to pod filling, could lead to the defoliation of flower buds. However, the delay in the supply of irrigation water cannot always compensate for the damage [52].

The need for irrigation should be different among the systems, due to different sowing dates and water loss during termination. The negative effects of the rolled rye treatment on soybean yield reported by Davis [17] may have been caused by continued water use of cover crops crimped. In conservation tillage systems, the recommended rye termination date is 4 weeks prior to the soybean planting date [27], to minimize the problems of emergence as a result of soil water depletion.

The higher weed biomass on the irrigated plots can be attributed to the higher moisture in the topsoil, which stimulated the germination of weed seeds that could compete better with the soybeans. Ferdous et al. [53] reported a significant increase of weed dry matter at 40 days after planting in irrigated plots than in non-irrigated plots. In contrast, many previous studies reported that weed resurgence was not affected by irrigation significantly. This complete soybean canopy formed during 
the growing season can increase weed suppression and weed biomass better in the irrigated than non-irrigated plots [54].

\subsection{Economic Assessment}

The soybean revenue in system (C) were higher because of higher soybean yield. Although, low grain yields of soybean in system (B) had a negative effect on the total revenue, high prices for organic soybean of $800 € \mathrm{ha}^{-1}$ versus $380 € \mathrm{ha}^{-1}$ for conventional soybean could compensate for the lower yields resulting in an overall positive gross margin.

The highest variable cost of introducing rye as a cover crop in system (A) would be covered by selling the rye biomass as animal feed (at $456 € \mathrm{ha}^{-1}$ ). In general, conservation systems (B) and (C) appeared to perform better with irrigation, where competition for water reduced, resulting enhanced crop growth and increased revenues. This potentially enhanced returns on investment, as demonstrated by Snapp et al., [51]. An additional benefit of cover crops is that they can reduce nitrate leaching during winter [16], although, currently, this is not a sufficient incentive to overcome the additional costs from growing cover crops.

\section{Conclusions}

This study demonstrated the high efficiency of no-tillage cover-crop systems in controlling weeds during soybean growing season. Soybean yield was lower for the no-tillage herbicide-free system, which could be attributed to the late cover crop termination date in this system. The low soybean yield for the herbicide-free system resulted in low revenues and gross margins, which would only be economically attractive in organic farming, where the selling price of soybean is relatively higher.

Although irrigation promoted weed growth, it also increased soybean yields in all cropping systems. The additional costs of irrigation were covered by the higher revenues resulting from higher soybean yields in dry years, as observed in 2016.

We conclude that more investigations on the benefits and risks of no-tillage cover-crop management are needed before the technique can be recommended for the conditions tested in north-eastern Germany. Future research needs to focus on maintaining high rye biomass, ensuring an early rye termination and soybean planting date, optimizing the crimping and drilling equipment in order to develop good management practices in no-tillage herbicide-free systems for European conditions.

Author Contributions: R.B., J.B. and M.R. conceived and designed the experiments. M.H. and M.R. performed the agronomic and J.S. and R.B. performed the economic analysis. M.H. wrote the manuscript and all authors contributed.

Funding: This work was funded by the Federal Ministry of Education and Research (BMBF) Germany with the FACCE-JPI ERA-NET+ Project Climate-CAFE (Grant PTJ-031A544), the Innovation Network to Improve Soybean Production under the Global Change (INNISOY) through the European Interest Group CONCERT-Japan (01DR17011A) and the SusCrop- ERA-NET project LegumeGap (031B0807B). Moritz Reckling was funded by the Deutsche Forschungsgemeinschaft (DFG, German Research Foundation) - 420661662.

Acknowledgments: The authors would like to cordially thank Gunhild Rosner, Gerlinde Stange and the field research station in Müncheberg for their excellent technical support and establishment of the technically challenging field experiments.

Conflicts of Interest: The authors declare no competing financial interests in relation to the work described.

\section{References}

1. Olesen, J.E.; Trnka, M.; Kersebaum, K.C.; Skjelvåg, A.O.; Seguin, B.; Peltonen-Sainio, P.; Rossi, F.; Kozyra, J.; Micale, F. Impacts and adaptation of European crop production systems to climate change. Eur. J. Agron. 2011, 34, 96-112. [CrossRef]

2. Vadez, V.; Berger, J.D.; Warkentin, T.; Asseng, S.; Ratnakumar, P.; Rao, K.P.C.; Gaur, P.M.; Munier-Jolain, N.; Larmure, A.; Voisin, A.-S.; et al. Adaptation of grain legumes to climate change: A review. Agron. Sustain. Dev. 2011, 32, 31-44. [CrossRef] 
3. Reckling, M.; Döring, T.F.; Bergkvist, G.; Stoddard, F.L.; Watson, C.A.; Seddig, S.; Chmielewski, F.-M.; Bachinger, J. Grain legume yields are as stable as other spring crops in long-term experiments across northern Europe. Agron. Sustain. Dev. 2018, 38, 63. [CrossRef] [PubMed]

4. Doré, T.; Makowski, D.; Malézieux, E.; Munier-Jolain, N.; Tchamitchian, M.; Tittonell, P. Facing up to the paradigm of ecological intensification in agronomy: Revisiting methods, concepts and knowledge. Eur. J. Agron. 2011, 34, 197-210. [CrossRef]

5. Reckling, M.; Bergkvist, G.; Watson, C.A.; Stoddard, F.L.; Bachinger, J. Re-designing organic grain legume cropping systems using systems agronomy. Eur. J. Agron. 2020, 112, 125951. [CrossRef]

6. Reyer, C.; Bachinger, J.; Bloch, R.; Hattermann, F.F.; Ibisch, P.L.; Kreft, S.; Lasch, P.; Lucht, W.; Nowicki, C.; Spathelf, P.; et al. Climate change adaptation and sustainable regional development: a case study for the Federal State of Brandenburg, Germany. Reg. Environ. Chang. 2012, 12, 523-542. [CrossRef]

7. Reckling, M.; Döring, T.F.; Bergkvist, G.; Chmielewski, F.-M.; Stoddard, F.L.; Watson, C.A.; Seddig, S.; Bachinger, J. Grain legume yield instability has increased over 60 years in long-term field experiments as measured by a scale-adjusted coefficient of variation. Asp. Appl. Biol. 2018, 138, 15-20.

8. Reckling, M.; Bachinger, J.; Bellingrath-Kimura, S.D. Taking Soybean Cultivation Further North: Agronomic Performance of Cultivars and Irrigation Treatments. In Proceedings of the XVe European Society for Agronomy Congress (ESA), Geneva, Switzerland, 27-31 August 2018; pp. 91-92.

9. Salamanca, C.; Cid, P.; Gomez-Macpherson, H. Conservation agriculture implications for soil water balance. In A Modelling Approach, Proceedings of the 1st World Conference on Soil and Water Conservation under Global Change (CONSOWA), Lleida, Spain, 12-16 June 2017; Simó, I., Poch, R.M., Pla, I., Eds.; Diputació de Lleida: Lleida, Spain; p. 2017.

10. Flower, K.; Cordingley, N.; Ward, P.; Weeks, C. Nitrogen, weed management and economics with cover crops in conservation agriculture in a Mediterranean climate. Field Crops Res. 2012, 132, 63-75. [CrossRef]

11. Davis, A.S.; Renner, K.A.; Gross, K.L. Weed Seedbank and Community Shifts in a Long-Term Cropping Systems Experiment. Weed Sci. 2005, 53, 296-306.

12. Weber, J.F.; Kunz, C.; Peteinatos, G.G.; Zikeli, S.; Gerhards, R. Weed Control Using Conventional Tillage, Reduced Tillage, No-Tillage, and Cover Crops in Organic Soybean. Agriculture 2017, 7, 43. [CrossRef]

13. Tabaglio, V.; Gavazzi, C.; Schulz, M.; Marocco, A. Alternative weed control using the allelopathic effect of natural benzoxazinoids from rye mulch. Agron. Sustain. Dev. 2008, 28, 397-401. [CrossRef]

14. Plaza-Bonilla, D.; Nolot, J.-M.; Raffaillac, D.; Justes, E. Cover crops mitigate nitrate leaching in cropping systems including grain legumes: Field evidence and model simulations. Agric. Ecosyst. Environ. 2015, 212, 1-12. [CrossRef]

15. Thapa, B.; Pande, K.R.; Khana, B.; Marahatta, S. Effect of Tillage, Residue Management and Cropping System on the Properties of Soil. Int. J. Appl. Sci. Biotechnol. 2018, 6, 164-168. [CrossRef]

16. Justes, E. Cover Crops for Sustainable Farming; Springer Nature: GX Dordrecht, The Netherlands, 2017. [CrossRef]

17. Davis, A.S. Cover-Crop Roller-Crimper Contributes to Weed Management in No-Till Soybean. Weed Sci. 2017, 58, 300-309. [CrossRef]

18. Keene, C.L.; Curran, W.S.; Wallace, J.M.; Ryan, M.R.; Mirsky, S.B.; VanGessel, M.J.; Barbercheck, M.E. Cover Crop Termination Timing is Critical in Organic Rotational No-Till Systems. Agron. J. 2017, 109, $272-282$. [CrossRef]

19. Bloch, R. The Vulnerability of Organic Farming to Climate Change Effects in the Federal State of Brandenburg, Germany; Kassel University Press: Kassel, Germany, 2016.

20. Mirschel, W.; Klauss, H.; Berg, M.; Eisenhut, K.-U.; Ißbrücker, G.; Prochnow, A.; Schörling, B.; Wenkel, K.-O. Innovative Technologien für eine effiziente Bewässerung im Pflanzenbau. In Land- und Ernährungswirtschaft im Klimawandel-Auswirkungen, Anpassungsstrategien und Entscheidungshilfen; Bloch, R., Bachinger, J., Fohrmann, R., Pfriem, R., Eds.; oekom verlag: München, Germany, 2014; pp. 261-277.

21. Vincent-Caboud, L.; Casagrande, M.; David, C.; Ryan, M.R.; Silva, E.M.; Peigne, J. Using mulch from cover crops to facilitate organic no-till soybean and maize production. A review. Agron. Sustain. Dev. 2019, $39,45$. [CrossRef]

22. Carr, P. Guest Editorial: Conservation Tillage for Organic Farming; Multidisciplinary Digital Publishing Institute: Basel, Switzerland, 2017. 
23. Werle, R.; Burr, C.; Blanco-Canqui, H. Cereal rye cover crop suppresses winter annual weeds. Can. J. Plant Sci. 2017, 98, 498-500. [CrossRef]

24. Clark, K.M.; Boardman, D.L.; Staples, J.S.; Easterby, S.; Reinbott, T.; Kremer, R.J.; Kitchen, N.R.; Veum, K.S. Crop yield and soil organic carbon in conventional and no-till organic systems on a claypan soil. Agron. J. 2017, 109, 588-599. [CrossRef]

25. Twidwell, E.K.; Beutler, M.; Kephart, K.; Boe, A. Grass Seed Production in South Dakota Guidelines; Agricultural Experiment Station Circulars: Logan, UT, USA, 1987.

26. De Bruin, J.L.; Porter, P.M.; Jordan, N.R. Use of a rye cover crop following corn in rotation with soybean in the upper Midwest. Agron. J. 2005, 97, 587-598. [CrossRef]

27. Ashford, D.L.; Reeves, D.W. Use of a mechanical roller-crimper as an alternative kill method for cover crops. Am. J. Altern. Agric. 2003, 18, 37-45. [CrossRef]

28. Wells, M.S.; Brinton, C.M.; Reberg-Horton, S.C. Weed suppression and soybean yield in a no-till cover-crop mulched system as influenced by six rye cultivars. Renew. Agric. Food Syst. 2015, 31, 429-440. [CrossRef]

29. Smith, A. Utilizing Rolled Rye Mulch for Weed Suppression in Organic No-Tillage Soybeans. Master's Thesis, Faculty of North Carolina State University, Raleigh, NC, USA, 2010.

30. Basche, A.D. Climate-Smart Agriculture in Midwest Cropping Systems: Evaluating the Benefits and Tradeoffs of Cover Crops; Iowa State University: Ames, IA, USA, 2015.

31. Williams, M.M.N.; Mortensen, D.A.; Doran, J.W. No-tillage soybean performance in cover crops for weed management in the western Corn Belt. J. Soil Water Conserv. 2000, 55, 79-84.

32. Silva, E.M.; Vereecke, L. Optimizing organic cover crop-based rotational tillage systems for early soybean growth. Org. Agric. 2019,1-11. [CrossRef]

33. Bernstein, E.R.; Posner, J.L.; Stoltenberg, D.E.; Hedtcke, J.L. Organically managed no-tillage rye-soybean systems: agronomic, economic, and environmental assessment. Agron. J. 2011, 103, 1169-1179. [CrossRef]

34. Mirsky, S.; Curran, W.S.; Mortensen, D.A.; Ryan, M.; Shumway, D. Control of cereal rye with a roller/crimper as influenced by cover crop phenology. Agron. J. 2009, 101, 1589-1596. [CrossRef]

35. Georgel, F. Agroecological service crop termination with a roller-crimper in organic vegetable systems: A good alternative to conventional soil tillage? Norwegian University of Life Sciences: Ås, Norway, 2017.

36. Liebert, J.; Ryan, M. High Planting Rates Improve Weed Suppression, Yield, and Profitability in Organically-Managed, No-till-Planted Soybean. Weed Technol. 2017, 31, 536-549. [CrossRef]

37. Aigner, A. Erkenntnisse aus den bayerischen Sojaversuchen. In Proceedings of the Fünf Jahre Soja-Netzwerk Wertschöpfungsketten und Impulse für die Zukunft, Würzburg, Germany, 23-24 October 2018; pp. 6-8.

38. Recknagel, J. Sojaanbau in Deutschland -Stand und Perspektiven. In Proceedings of the Fünf Jahre Soja-Netzwerk Wertschöpfungsketten und Impulse für die Zukunft, Würzburg, Germany, 23-24 October 2018; pp. 2-5.

39. Mandić, V.B.Z.; Krnjaja, V.; Simić, A.; Ružić-Muslić, D.; Dragičević, V.; Petričević, V. The rainfall use efficiency and soybean grain yield under rainfed conditions in Vojvodina. Biotechnol. Anim. Husb. 2017, 33, 475-486. [CrossRef]

40. Mirsky, S.B.; Ryan, M.R.; Teasdale, J.R.; Curran, W.S.; Reberg-Horton, C.S.; Spargo, J.T.; Wells, M.S.; Keene, C.L.; Moyer, J.W. Overcoming weed management challenges in cover crop-based organic rotational no-till soybean production in the eastern United States. Weed Technol. 2013, 27, 193-203. [CrossRef]

41. Frederick, J.R.; Bauer, P.J.; Busscher, W.J.; Mc Cutcheon, G.S. Tillage management for double cropped soybean grown in narrow and wide row width culture. Crop Sci. 1998, 38, 755-762. [CrossRef]

42. Kurasch, A.K.; Leiser, W.L.; Würschum, T.; Hahn, V. Identifizierung von Mega-Umwelten in Europa und Effekte der Reifegene auf die Anpassung europäischer Sojasorten. In Proceedings of the Soja-Tagung, Rastatt, Germany, 2017; pp. 72-73.

43. Linkemer, G.; Board, J.E.; Musgrave, M.E. Water logging effects on growth and yield components in lateplanted soybean. Crop Sci. 1998, 38, 1576-1584. [CrossRef]

44. Mirsky, S.B. Evaluating Constraints and Opportunities in Managing Weed Populations with Cover Crops. Ph.D. Thesis, Penn State University, Centre County, PA, USA, 2008.

45. Alonso-Ayuso, M.; Luis Gabriel, J.; Quemada, M. The Kill Date as a Management Tool for Cover Cropping Success. PLoS ONE 2014, 9, 12. [CrossRef] [PubMed]

46. Idowu, J.; Grover, K. Principles of Cover Cropping for Arid and Semi-Arid Farming Systems; New Mexico State University, College of Agricultural, Consumer and Environmental Sciences: Las Cruces, New Mexico, 2014. 
47. Legleiter, T.; Johnson, B.; Young, B.G. Successful Annual Ryegrass Termination with Herbicides; Purdue University: West Lafayette, Indiana, 2015; p. 4.

48. Smith, A.N.; Chris Reberg-Horton, S.; Place, G.T.; Meijer, A.D.; Arellano, C.; Mueller, J.P. Rolled Rye Mulch for Weed Suppression in Organic No-Tillage Soybeans. Weed Sci. Soc. Am. 2011, 59, 224-231. [CrossRef]

49. Wittwer, R.A.; Dorn, B.; Jossi, W.; Van Der Heijden, M.G. Cover crops support ecological intensification of arable cropping systems. Sci. Rep. 2017, 7, 41911. [CrossRef]

50. Sadeghipour, O.; Abbasi, S. Soybean response to drought and seed inoculation. World Appl. Sci. J. 2012, 17, 55-60.

51. Snapp, S.; Swinton, S.; Labarta, R.; Mutch, D.; Black, J.; Leep, R.; Nyiraneza, J.; O'neil, K. Evaluating cover crops for benefits, costs and performance within cropping system niches. Agron. J. 2005, 97, 322-332.

52. Kokubun, M. Physiological mechanisms regulating flower abortion in soybean. In Soybean-Biochemistry, Chemistry and Physiology; IntechOpen: Rijeka, Croatia, 2011.

53. Ferdous, Z.; Datta, A.; Anwar, M. Plastic mulch and indigenous microorganism effects on yield and yield components of cauliflower and tomato in inland and coastal regions of Bangladesh. J. Crop Improv. 2017, 31, 261-279. [CrossRef]

54. Yelverton, F.H.; Coble, H.D. Narrow row spacing and canopy formation reduces weed resurgence in soybeans (Glycine max). Weed Technol. 1991, 5, 169-174. [CrossRef]

(C) 2019 by the authors. Licensee MDPI, Basel, Switzerland. This article is an open access article distributed under the terms and conditions of the Creative Commons Attribution (CC BY) license (http://creativecommons.org/licenses/by/4.0/). 